\title{
AGRICULTURE AND PLANTATION MANAGEMENT TO SUPPORT THE EMPOWERMENT OF RURAL ISLAMIC BOARDING SCHOOL (CASE STUDY IN ISLAMIC BOARDING SCHOOL ABDUSSALAM)
}

\section{MANAJEMEN PERTANIAN DAN PERKEBUNAN UNTUK MENDUKUNG PEMBERDAYAAN PONDOK PESANTREN PEDESAAN (STUDI KASUS DI PONDOK PESANTREN ABDUSSALAM)}

\author{
A. Alhifni1a, B. Ahwarumi² \\ 1aPostgraduate Airlangga University, Jl. Airlangga 4-6, Surabaya - 60286/Islamic Bank \\ Study, Islamic Economic Faculty of Djuanda University, Jalan Tol Ciawi No. 1,16720, \\ e-mail: alhifniui@gmail.com/anas.alhifni@unida.ac.id \\ 2Sunan Drajat Institute, Jalan Raden Qosim Banjar Anyar Lamogan Indonesia, 62264, \\ e-mail: ahwarumi@gmail.com
}

\begin{abstract}
Islamic Boarding School Abdussalam is located in rural areas of West Kalimantan and has agriculture and plantation sectors. The purpose of this study is to find out how the agricultural management system implemented by Islamic Boarding School. This research uses qualitative approach with phenomenology analysis technique. The results show that agricultural and plantation conditions in Islamic Boarding School Abdussalam have been empowered and have given economic independence to Islamic Boarding School although only managed by traditional system, from both sectors of agriculture sector have bigger result than plantation sector. The proposed agriculture and plantation management design resulting from this research is modern management based on solving the main problems faced by both sectors, such as weakness of governance system, lack of profersional human resources, limited infrastructure and capital, through cooperation with some related institutions such as government, universities, and companies that are directly related to the agricultural and plantation sectors in Islamic Boarding School Abdussalam. Originality of research, such a study has never been done before because in this study described the management system and level of empowerment of agriculture and plantation Islamic Boarding School Abdussalam.
\end{abstract}

Keywords: Islamic Boarding School Abdussalam, Empowerment, Agriculture and Plantation

\begin{abstract}
ABSTRAK
Pondok Pesantren Abdussalam terletak di daerah pedesaan Kalimantan Barat dan memiliki sektor pertanian dan perkebunan. Tujuan penelitian ini adalah untuk mengetahui bagaimana sistem manajemen pertanian dilaksanakan oleh Pondok Pesantren. Penelitian ini menggunakan pendekatan kualitatif dengan teknik analisis fenomenologi. Hasil penelitian menunjukkan bahwa kondisi pertanian dan perkebunan di Pondok Pesantren Abdussalam telah diberdayakan dan telah memberikan kemandirian ekonomi kepada Pondok Pesantren meskipun hanya dikelola oleh sistem tradisional. Dari kedua sektor tersebut sektor pertanian memiliki hasil yang lebih besar
\end{abstract}


daripada sektor perkebunan. Usulan desain manajemen pertanian dan perkebunan yang dihasilkan dari penelitian ini adalah manajemen modern yang didasarkan pada pemecahan masalah utama yang dihadapi oleh kedua sektor, seperti kelemahan sistem pemerintahan, kurangnya sumber daya manusia yang profesional, infrastruktur dan modal yang terbatas, melalui kerja sama dengan beberapa institusi terkait, seperti pemerintah, universitas, dan perusahaan yang terkait langsung dengan sektor pertanian dan perkebunan di Pondok Pesantren Abdussalam. Orisinalitas penelitian, penelitian semacam itu belum pernah dilakukan sebelumnya karena dalam penelitian ini dijelaskan sistem manajemen dan tingkat pemberdayaan pertanian dan perkebunan Pondok Pesantren Abdussalam.

Kata Kunci: Pondok Pesantren Abdussalam, Pemberdayaan, Pertanian dan Perkebunan

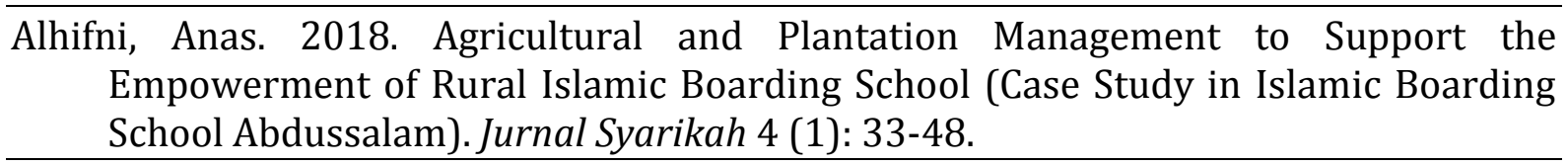

\section{INTRODUCTIONS}

Islamic Boarding School in Indonesia is an Islamic educational institution that is also an economic institution, many Islamic Boarding Schools have business sectors such as agriculture and others, business sector is used to maintain the economic independence of Islamic Boarding School so that its sustainability is maintained well. Land of agricultural land is generally managed by the community both independently and group, agricultural land and plantation in Islamic Boarding School is managed by student and community (Adikrishna, 2011; Rudi, et al 2014; Abdurrachim, 2015; Sari, 2016), the harvest from the land generally used also by students for consumption needs as done in Islamic Boarding School Abdussalam although with the traditional management but has given independence to the Islamic Boarding School. In accordance with the development of the era, the agricultural management system continues to grow, so Islamic Boarding School needs to adjust to these developments ranging from planting, irrigation, maintenance, marketing and other systems so that the results obtained can be optimized. Based on the formulation of the above problem the researcher wants to know how the system of agriculture and plantation management in Islamic Boarding School Abdussalam so as to give independence to Islamic Boarding School, and how the researcher proposal about the management of agriculture and plantation in Islamic Boarding School so that can get more optimal result.

\section{LITERATURE REVIEW AND RESEARCH METHODS}

\section{Islamic Boarding School}

At the beginning of its emergence, Islamic Boarding School only became a traditional Islamic educational institution that teaches religious knowledge, especially aqidah, morality and fiqih (Arwiya, 2015), but in accordance with the development of Islamic Boarding School era growing and also began to open business units to support sustainability Islamic Boarding School. Generally Islamic Boarding School in Indonesia has three forms namely Islamic Boarding School salafiyah, khalafiyah and 
modern, from the three forms (Ashrohah, 2011; Bakhri, 2011; Basri, 2014; Sulaiman, 2016). Islamic Boarding School Abdussalam is classified as khalafiyah because it has combined modern system with salafiyah system. Islamic Boarding School Abdussalam also has many business units such as plantations, agriculture, trade, livestock and financial services, the name of which is discussed in this particular research of the agricultural sector, because of all the existing sectors, agriculture and plantation sector is the largest sector especially in producing profit (Fauzan, 2006; Muttaqih, Rizal, 2011; Alhifni, 2016; Anam, 2016).

\section{Economic Empowerment}

Economic empowerment is an effort to make the economy strong, big, modern, and highly competitive. The theory that is in line with economic empowerment is the theory of economic growth described by Schumpeter according to him in empowerment is very important role of entrepreneurs in realizing economic growth, it shows that entrepreneurs are a group that will continuously make renewal or innovation in economic activity so that economic activity can spread and the previously helpless to be empowered (Sukirno, 2003; Astuti, 2012; Mulkan, 2013). Such innovations include introducing new goods, improving efficiency, exploring ways of producing, creating opportunities, expanding market access and more, in addition, empowerment consists of processes and outcomes. There are two strategies in empowering the first to prepare the private community to become entrepreneurs, the two do the assistance so that the activities in accordance with the procedure and the results obtained more optimal (Ambar, 2004; Adi, 2008; Indrawati, 2013; Thahir, 2014).

Empowerment means providing resources, opportunities, knowledge, and skills in improving the community's ability to determine a better future (Ife, 2008). Empowerment has a goal to provide the capability to people, especially vulnerable and weak groups so that they have the power to be selfsufficient in meeting their life needs (Suharto, 2006). Empowerment is divided into two levels: individual and group level. Empowerment theory at the individual level sees individual learning and seeks to achieve its objectives, at the group level looking at how awareness and community participation grow together to utilize resources to have better benefits (Wekke, 2013). Sudantoko (2011) explains that there are several steps to measure the level of empowerment as follows:

1. Business access

Have sufficient business access, such as availability of capital, facilities, and infrastructure, the supply of goods, distribution of goods.

2. Market access

Have adequate market access, can market the product well and easily accessible by the community, and can compete well with similar businesses and others.

3. Access technology

Have sufficient technological access to support business sustainability, in order to facilitate transactions, transparency and business accountability

4. Access human resources

Have access to the availability of professional human resources, especially in business management

5. Lobbying, its relationship with stakeholders and business sustainability.

The involvement of Masyarakat, has a good relationship with stakeholders of existing economic institutions, especially in the sustainability of the business undertaken.

When all the access goes well it can be concluded that the economic activity has provided economic independence or 
is empowered if only one of them is said to be less empowered, but if from the five such access has not been done indicates that empowerment is not yet empowered. Isma'il (2001) describes the economic empowerment of society can be done with four things:

1. Has the ability to meet the basic needs of life and a stable economy.

2. Have the ability to adapt to environmental changes.

3. Have the ability to deal with threats and attacks from outside.

4. Have the ability to create and innovate.

\section{Research methods}

This research uses the qualitative approach with phenomenology technique, the use of the technique to see clearly the condition of the agricultural management system that has been done in Islamic Boarding School Abdussalam. The data collecting technique is an interview with the headboard of Islamic Boarding School Abdussalam (KH Hafiluddin) and agriculture manager, to see the appropriateness of interview result with the reality of the researcher also conducting participant observations directly in agriculture and plantation of Islamic Boarding School Abdussalam plus documentation of sector report data agriculture.

\section{RESEARCH RESULT}

\section{Agriculture Empowerment at Islamic Boarding School Abdussalam}

To facilitate the readers, researchers describe the agricultural sector in Islamic Boarding School Abdussalam explained based on the criteria of empowerment of the sector such as access to business, market, human resources, and lobbying so that the level of empowerment of the agricultural sector can be easier to know.

1. Agricultural Business Access at Islamic Boarding School Abdussalam
Islamic Boarding School Abdussalam started to develop rice farming in 2010, the land available at that time amounted to 10 hectares, the location of the land is $3 \mathrm{KM}$ from Islamic Boarding School, every year Islamic Boarding School Abdussalam buy new land and until now the land has been increased to become 25 hectares, 20 hectares are located in one location and 5 hectares are located in different locations, of the total land is only 8 hectares productive and 17 hectares is still not productive, due to limited capital and human resources who are experts in agriculture. Ownership of agricultural land in Islamic Boarding School Abdussalam is the private property of head of Islamic Boarding School Abdussalam as much as 23 hectares and 2 hectares owned by Mr. Sulaiman (the Leader who also helps the sector). Agricultural land in Islamic Boarding School Abdussalam is managed independently from the cultivation process and the seeding process.

The seeding process is done independently, the type of commonly used rice seedlings are A5, A5e, ampara 11 , and ampara 8 purchased from Pontianak City, the seed is subsidized seed, every time spend $200 \mathrm{~kg} \mathrm{~s} / \mathrm{d} 300 \mathrm{~kg}$ seeds, 2 tons subsidized fertilizer with an average price of Rp.14.000 / kg, the irrigation system used to use rainfed, because the new irrigation system will be implemented next year. The source of capital for the seed purchase comes from the leadership of Islamic Boarding School Abdussalam and the government (Gapoktan: a combination of farmer groups). The existence of an Islamic Boarding School Abdussalam has existed since five years ago although its existence has not run optimally because the farmer groups coming from many people who have not participated optimally. While the capital derived from BMT Barokah Abdussalam to date has not been there, 
because according to the leadership of Islamic Boarding School Abdussalam no BMT products that can accommodate the sector. The obstacles faced from business access as the results of interviews:

What are the constraints faced especially regarding access to agricultural business in Islamic Boarding School Abdussalam?

Obstacles fewer capital packs, because the seeds are quite expensive as well and transportation constraints here are expensive, the road is also damaged and can only motor.

The interview shows that the access of agricultural business in Islamic Boarding School Abdussalam is less empowered although the land, seeds, fertilizers can be accessed, this is because there are still many lands that have not been cultivated as agricultural land due to limited capital and human resources, the existence not yet running optimally some factors such as, lack of interest of the community to farm, the community does not have land and only as a cultivator, the lack of knowledge owned, so the is only run by student and kiyai, other obstacles faced agriculture is the number of rice affected by pests and rats.

2. Agricultural Market Access at Islamic Boarding School Abdussalam

Agricultural land in Islamic Boarding School never produces twice, because the season is too extreme, for rice harvest is usually done 2 to 3 times a year with an average harvest of 40 bags with a weight of $30 \mathrm{~kg}$ each, while for machining process is done independently. The system of distribution of crops in Islamic Boarding School is not sold out but sold on the Islamic Boarding School as a subsidized consumption of student so that the cost of student consumption can be cheaper and affordable. In general, the land is already empowered because in each year income and can help the consumption of student, the plan of the Board of Islamic Boarding School will expand agricultural land, especially maximizing the management of land that has been productive and working on lands that have not been productive. Expansion of the land is expected to provide greater benefits, and not only can be utilized by the student but can be utilized by the community and sold in the market so that the proceeds from the sale can also be used to support the empowerment of Islamic Boarding School.

In general, constraints faced by the agricultural sector, especially in the market access are transportation constraints, the condition of the place in the interior, the four-wheeled special road infrastructure has not been available causing the price of seeds, fertilizers and others become more expensive, it also causes the reluctance of managers to sell agricultural products to the market, the selling price is cheaper than the market price because the cost of shipping cost is relatively more expensive. The obstacles faced from access to agricultural business as the results of interviews:

What are the constraints faced in developing the agricultural market access in Islamic Boarding School, do you already have enough market access?

Farmers we have the results, only two times can, we difficult constraints expensive transportation, hard buying, because the price is so cheap so we sell to the cottage for students, sometimes also price ama people too

The interview result shows that agricultural market access in Islamic Boarding School Abdussalam has been running well because the result of agriculture has been utilized to help students and the community, although the harvest has not been sold or marketed 
widely due to various obstacles such as lack of access to transportation and low selling price. One strategy to expand the market access of Islamic Boarding School Abdussalam is to cooperate with the trade sector in Islamic Boarding School Abdussalam so that the harvested products can be marketed or sold to the public through the sector.

3. Access to Agricultural Information Technology at Islamic Boarding School Abdussalam

The process of rice cultivation, already using relatively modern equipment such as sickle, machetes, spraying, tractors, buckets, nets, hoes, water machines, and rice mills, there is some subsidized equipment from the government ie 2 units of tractors. While the reporting system has not been conducted regularly and does not use modern systems, the reporting system is still limited to oral and only reported to the leadership with a belief system, due to the limited knowledge of student regarding the reporting system especially related to administration and finance. Researchers and some students have provided administrative and financial training for agricultural managers and provided a unit of the computer so that managers can report regularly with better and transparent reporting systems. The results of the training, current managers have been able to create financial reports and assisted by researchers, the following is the financial report of the agricultural sector that has been made:
Table 1. Balance of Agriculture December 31, 2016

\begin{tabular}{|l|c|l|l|}
\hline \multicolumn{2}{|c|}{ Assets } & \multicolumn{2}{c|}{ Pasiva } \\
\hline Current Asset & (in rupiah) & & (in rupiah) \\
\hline $\begin{array}{l}\text { Supplies of } \\
\text { seeds, } \\
\text { fertilizers and } \\
\text { pesticides }\end{array}$ & 12.200 .000 & Capital & 23.806 .394 .400 \\
\hline Fixed Asset & & & \\
\hline $\begin{array}{l}\text { Agricultural } \\
\text { Land }\end{array}$ & 24.000 .000 .000 & Profit & 244.245 .200 \\
\hline $\begin{array}{l}\text { Agiricultural } \\
\text { Equipment }\end{array}$ & 41.864 .400 & & \\
\hline $\begin{array}{l}\text { Depreciation of } \\
\text { Agricultural } \\
\text { Equipment }\end{array}$ & -13.954 .800 & & \\
\hline Equipment & 10.530 .000 & & $\mathbf{2 4 . 0 5 0 . 6 3 9 . 6 0 0}$ \\
\hline Total & $\mathbf{2 4 . 0 5 0 . 6 3 9 . 6 0 0}$ & Total & \\
\hline
\end{tabular}

Source: Agricultural Sector Financial Report

Table. 2. Profit and Loss Agriculture 01 January - 31 December 2016

\begin{tabular}{|l|l|c|}
\hline \multicolumn{1}{|c|}{ Details } & \multicolumn{2}{c|}{ Balance } \\
\hline Income & $\begin{array}{l}\text { (in } \\
\text { Rupiah) }\end{array}$ & \\
\hline $\begin{array}{l}\text { Harvest } \\
\text { Revenue }\end{array}$ & 316.800 .000 & \\
\hline Cost & & 5.200 .000 \\
\hline $\begin{array}{l}\text { Breeding } \\
\text { Cost }\end{array}$ & & 5.000 .000 \\
\hline Fertilizer Fee & & 2.000 .000 \\
\hline $\begin{array}{l}\text { Pesticide } \\
\text { Expenses }\end{array}$ & & 52.354 .800 \\
\hline $\begin{array}{l}\text { Operating } \\
\text { Cos }\end{array}$ & & 8.000 .000 \\
\hline Other Cos & & $\mathbf{7 2 . 5 5 4 . 8 0 0}$ \\
\hline Total Cost & & $\mathbf{2 4 4 . 2 4 5 . 2 0 0}$ \\
\hline Net Income & & \\
\hline
\end{tabular}

Source: Agricultural Sector Financial Statement,

The two tables above show that both financial statements are made after collecting data collected as a form of action researcher and report manager of Islamic Boarding School on the activities of agriculture sector during the year 2016, the report shows that the agricultural sector in Islamic Boarding School Abdussalam has generated net income of Rp.244.245.200. 
4. Agricultural Human Resources Access at Islamic Boarding School Abdussalam

The management system is managed by students who are obedient and very loyal (dedicated to teachers and Islamic Boarding School), there is a special manager in charge of maintaining and caring for rice as many as 14 people from 07.00 to 17.00 , the students are assigned as the responsibility of agriculture sector especially for the students in the period of dedication, to maximize the management, in one week two times the students assisted by other students as much as 70 people, this is also the introduction of agriculture for students to build self-reliance students, while for the system of wage management is given in the form of wages that can be consumed by students so the students no longer need to pay the cost of consumption in Islamic Boarding School Abdussalam.

To increase the ability of students in managing agriculture, until now there has been no government and private institutions that provide training for students except the administrative and financial training provided by researchers, but for the next Islamic Boarding School Abdussalam has done Mou with the Faculty of Islamic Economics Djuanda University, especially in providing training for agricultural managers in the Islamic Boarding School. In the quantity of existing human resources is enough but their skills are very standard because learning more through the process of seeing other students and self-taught learning, so the ability of students in farming is very limited. The obstacles faced from access to agricultural business as the results of interviews:

What are the constraints faced, especially in the availability of human resources management of agriculture in Islamic Boarding School Abdussalam?

no training so on the less expert, we learn from Kiyai, sometimes like one too, continuing students who work is student long term so fitting home instead must be taught again pack.

The interviews indicate that students who are responsible for agriculture generally are students devotees who for one year or a maximum of two years so that when replaced by students subsequent devotion sometimes require a long process in understanding the method of farming is good. The access of human resources of agriculture sector in Islamic Boarding School Abdussalam has been running well because the quantity of human resources that manage is enough, and in general human resources are very obedient human resources to the Kiyai, although there are some weaknesses such as unavailability of human resources expert in agriculture.

5. Lobbying Agriculture Access at Islamic Boarding School Abdussalam

Some of the lands are managed by people around the Islamic Boarding School as much as 2 hectares, the management system is managed by the community itself, especially the people with the background of the alumni of Islamic Boarding School Abdussalam, the resulting harvest is divided by 7: 3 share sharing system, the Islamic Boarding Schools are all given to the underprivileged. For the status of land ownership, the managers of Islamic Boarding School have given the opportunity to the community to cooperate especially in land ownership, but until now not many people are interested in farm because the condition of stake area generally does not plant rice but rubber gardening. The obstacles faced from access to agricultural business as the results of interviews: 
What are the constraints faced especially in meeting the lobbying access or students or society in the agricultural sector in Islamic Boarding School Abdussalam?

If students involved in the pack, all students who manage, so there are obstacles, if people participate in routine work but sometimes help here people like to farm, but usually later harvest community likes also ama Kiyai

The interview shows that the condition of the people who prefer gardening rather than farming so that there is a reluctance of the community to farm, but in general the agricultural activities in Islamic Boarding School Abdussalam already have good relationship with all stakeholders so that the sustainability of their business can be well maintained, because all Stakeholder Islamic Boarding School Abdussalam has been involved in agricultural activities at Islamic Boarding School Abdussalam, all managers come from student and some people, the result was re-used for the welfare of student and community

\section{Plantation Sector}

The discussion on the plantation sector focuses on access to businesses, markets, human resources and lobbying so that the level of empowerment of the plantation sector can be more easily known.

1. Access to Plantation Enterprises at Islamic Boarding School Abdussalam

Plantation at Islamic Boarding School Abdussalam starting in 1999, the ownership status of the whole land belongs to the leadership of Islamic Boarding School Abdussalam so that all the management of the land is under the responsibility of the landowner. Plantation land so far has shown significant development, because this species has many types of crops grown such as rubber plantations, coffee, legumes, and vegetables. Rubber plantations started in 1999, 20 hectares of rubber plantation area, 10 hectares of coffee, and 2 hectares of coriander, and there are still about 10 hectares unproductive.

Capital owned is still derived from the leadership of Islamic Boarding School and no one came from BMT or from outsiders, for the next will cooperate with BMT especially in the addition of capital so that the development of plantations in Islamic Boarding School more developed again. The obstacles faced by the plantation sector in Islamic Boarding School Abdussalam are the constraints on the limited access of transportation and capital facilities so that if the result of the plantation wants to be sold the price is much cheaper because of the expensive transportation cost. Plantation crops such as coffee and rubber are both pre-existing (starting land purchase) so they do not require capital for seed purchases, only maintenance, and other costs are required, the maintenance of rubber trees is done once every week when the rainwater. While for corianderand vegetables, seeds purchased from the market or from previous plant seeds, the maintenance system is done one week once. The obstacles faced from access to agricultural business as the results of interviews:

What are the constraints faced specifically regarding access to plantation business in Islamic Boarding School Abdussalam?

Less capital, less fertile land is rarely fertilized, sometimes the soil is too dry because of the dry season when the season sometimes floods rain.

Access to plantation business in Islamic Boarding School Abdussalam is less empowered although the land, seeds, fertilizers can be accessed, this is because there is still a lot of lands that has not 
been cultivated as plantation land due to limited capital and soil fertility, so it takes innovation such as irrigation to overcome flooding when rain, and a water spraying machine during the dry season.

2. Market Access Plantation at Islamic Boarding School Abdussalam

Rubber plantations in the Islamic Boarding School have seasonal results depending on the weather, because if the rain cannot be taken, while for coffee plantations in one year usually yield three times the harvest, corianderplantations in one year produce two harvests. Special rubber crops are produced outside due to limited equipment, coffee and selfprocessed crops are then sold to outsiders, the results are used for Islamic Boarding School operations, while vegetables are sometimes sold or directly given to students for consumption. Land ownership is actually enough because there is still some land that has not been worked on, and in general, the land is already empowered and has supported the economic independence of Islamic Boarding School. In general, market access is enough but the obstacle is the decline of rubber and corianderprices, the decline of the selling price of both types of crops greatly affect the development of Islamic Boarding School, especially in the development of facilities and infrastructure students. The ongoing plan to increase the market access of the Islamic Boarding School of Abdussalam will try to grow other crops, such as sugar cane and chili, so that if rubber and corianderprices which generally have large-scale decreased the selling price can be supported by other crops. The constraints faced by the plantation sector, especially market access as the result of the interview:

What are the constraints faced especially in the market access to the plantation in Islamic Boarding School, do you have enough market access yet?

Already pack, transportation constraints are worth the price goes down mainly coriander, the same rubber, so sales decline compared to the first, continue the results also go down because maybe the plants are rarely really fertilized

The interviews show that the market access to the plantation in Islamic Boarding School Abdussalam has been running well because the results of the plantations have been used, the vegetables for consumption of student coriander, coffee and rubber sales for the development of facilities Islamic Boarding School infrastructure even though its sales fell because the market price also keeps going down.

3. Access the Plantation Market at Islamic Boarding School Abdussalam

Rubber plantations in the Islamic Boarding School have seasonal results depending on the weather, because if the rain cannot be taken, while for coffee plantations in one year usually yields three crops, the coriander plantation in one year produces two harvests. Special rubber crops are produced outside due to limited equipment, coffee harvest and coriander processed by themselves and then sold to outsiders, the results are used for Islamic Boarding School operations, while vegetables are sometimes sold or directly given to students for consumption. Land ownership is actually enough because there is still some land that has not been worked on, and in general, the land is already empowered and has supported the economic independence of Islamic Boarding School. In general, market access is enough but the obstacle is the decline of rubber and corianderprices, the decline of the selling price of both types of crops greatly affect the development of Islamic Boarding School, especially in the 
development of facilities and infrastructure students. The ongoing plan to increase the market access of the Islamic Boarding School of Abdussalam will try to grow other crops, such as sugar cane and chili, so if the price of rubber and coriander generally have large-scale decreased the selling price can be supported by other crops. The constraints faced by the plantation sector, especially market access as the result of the interview:

What are the constraints faced especially in the market access to the plantation in Islamic Boarding School, do you have enough market access yet?

Already pack, transportation constraints are worth the price goes down mainly coriander, the same rubber, so sales decline compared to the first, continue the results also go down because maybe the plants are rarely really fertilized

The interviews show that the market access to the plantation in Islamic Boarding School Abdussalam has been running well because the results of the plantations have been used, the vegetables for consumption of student coriander, coffee and rubber sales for the development of facilities Islamic Boarding School infrastructure even though its sales fell because the market price also keeps going down. One strategy to expand the market access of Islamic Boarding School Abdussalam's estates is to increase the types of crops with higher selling value, and shorter cropping periods such as chilies and others, marketing techniques can work with the trade sector at Islamic Boarding School Abdussalam.

4. Information Technology Access to Plantations at Islamic Boarding School Abdussalam

The use of plantation equipment uses traditional tools that are purchased independently, such as tools, hoes, machetes, forks. The reporting system of plantation crops in Islamic Boarding School Abdussalam is reported by every chairman to the leadership of Islamic Boarding School, the reporting is done every time the harvest is only verbal and no reporting has been made using the computer system because the computer is not yet available.

The obstacles faced in the field of information Technology are the limited knowledge of administrators about administration and finance, but researchers for several months at the research site, researchers and some students provide administrative and financial training for plantation managers and are given a computer unit that can be used by the plantation sector. The results of the training, current managers have been able to create financial reports and assisted by researchers, the following is the financial report of the plantation sector that has been made:

Table 3. Plantation Balance December 31, 2016

\begin{tabular}{|c|c|c|c|}
\hline \multicolumn{2}{|c|}{ Assets } & \multicolumn{2}{|r|}{ Pasiva } \\
\hline $\begin{array}{c}\text { Fixed } \\
\text { Assets }\end{array}$ & (In Rupiah) & & (In Rupiah) \\
\hline $\begin{array}{l}\text { Estate } \\
\text { Plantation }\end{array}$ & 10.000 .000 .000 & Capital & 9.986 .905 .000 \\
\hline $\begin{array}{l}\text { Plantation } \\
\text { Equipment }\end{array}$ & 1.645 .000 & Profit & 14.770 .000 \\
\hline $\begin{array}{l}\text { Plantation } \\
\text { Equipment } \\
\text { tou }\end{array}$ & 30.000 & & \\
\hline $\begin{array}{l}\text { Total } \\
\text { Assets }\end{array}$ & 10.001 .675 .000 & $\begin{array}{l}\text { Total } \\
\text { Pasiva }\end{array}$ & 10.001 .675 .000 \\
\hline
\end{tabular}

Source: Plantation Sectors Finance Report, Data are processed 
Table 4. Profit and Loss Plantation 01 Januari - 31 Desember 2016

\begin{tabular}{|l|l|l|}
\hline \multicolumn{1}{|c|}{ Details } & \multicolumn{2}{c|}{ Balance } \\
\hline Income & & \\
\hline $\begin{array}{l}\text { Harvest } \\
\text { Revenue }\end{array}$ & $\begin{array}{l}\text { Rp } \\
\text { C9.150.000 }\end{array}$ \\
\hline Cost & & \\
\hline $\begin{array}{l}\text { Fertilizer } \\
\text { Fee }\end{array}$ & & Rp 90.000 \\
\hline $\begin{array}{l}\text { Operating } \\
\text { Cost }\end{array}$ & & Rp 34.290 .000 \\
\hline Total Cost & & $\begin{array}{l}\text { Rp } \\
\mathbf{3 4 . 3 8 0 . 0 0 0}\end{array}$ \\
\hline $\begin{array}{l}\text { Net } \\
\text { Income }\end{array}$ & $\begin{array}{l}\text { Rp } \\
\mathbf{1 4 . 7 7 0 . 0 0 0}\end{array}$ \\
\hline
\end{tabular}

Source: Plantation Sectors Finance Report, Data are processed

The two tables above show that both financial statements are made after the collective data collection as a form of action researcher and report manager on the activities of the plantation sector during the year 2016, the report shows that the plantation sector in 2016 generate profits of Rp.14.770.000, the lack of the result is due to the decline in the selling price of rubber and coriander prices so that both types of crops are not sold.

5. Access to Human Resources of Islamic Boarding School of Abdussalam

All plantation crops in the Islamic Boarding School are managed by loyal and loyal student, both active and student of service (student who have graduated from high school or vocational school) Islamic Boarding School does not involve workers or outside parties, and the answer is student specially designated, total of all plantation managers as many as 30 people consist of coriander10 people, rubber 10 people, coffee 5 people and vegetables 5 people. All managers are assisted by other students one week once as many as 70 people student if the work to be completed too much.

Until now there has been no specific training given except the administrative and financial training provided by the researcher so that there are no special partners either government agencies or others that provide training to plantation managers in Islamic Boarding School Abdussalam, lack of training provided and only self-taught lead to human resources which is currently in quantity is sufficient but the quality is still not reliable enough, but in the year 2017 Islamic Boarding School Abdussalam has done Mou with the Faculty of Islamic Economics Djuanda University to solve the problem. The constraints faced by the plantation sector, especially access to human resources as the result of interviews:

What are the constraints faced, especially in the availability of human resources management of agriculture in Islamic Boarding School Abdussalam?

$H R$ is still managing what there is pack, not experts

HR is enough?

It's pack, but yes so understand our regular student also ga no special training capital ta'dzim to Kiyai

The interviews show that the human resources who manage the only student who have the capital adhere to the same teacher and do not have special skills in the field of the plantation, the quantity of human resources is enough but not yet reliable so that the results obtained are not maximal. Despite these limitations, the plantation sector continues to produce, but the results are not yet optimal, so special strategies are needed to resolve the problem such as providing special training for plantation managers and students in general so that the transition of the response from senior students to junior student is not a 
problem. Mou who has done Islamic Boarding School Abdussalam can be utilized properly to support the strategy so that it can give birth to human resources that are ready and quality.

6. Access Lobbying Plantation at Islamic Boarding School Abdussalam

There is one hectare of land managed by the community and alumni, the management system uses a profitsharing system, after the plantation produces is usually sold on the side of Islamic Boarding School sells to outsiders, the proceeds of the sales are divided between the farmers while the part of Islamic Boarding School is used to help students who are not able. The relationship between Islamic Boarding School and the community is going well because in general, the surrounding community is also gardening, usually, the harvest of a part of zakat is given to the people around who are entitled to receive it.

As for land ownership to date all the existing land in Islamic Boarding School is owned by the leadership and no one owned by the community, because the surrounding community also has a large plantation area and is still unemployed, in fact, the Islamic Boarding School is very open if there is a community want to be in the land ownership with Islamic Boarding School, syirkah that has been run at this time new syirkah in the form of land management. The constraints faced by the plantation sector, especially access Lobbying as result of the interview:

What are the obstacles faced in meeting the access to lobbying plantations in Islamic Boarding School Abdussalam?

Here people have rubber garden same from the first so hard invited busy cooperation alone, but usually, people sell rubber products to Islamic Boarding, later Islamic Boarding School selling to the agent, there are also people who manage the land Kiyai if ga wrong use system for results

The interview shows that Islamic Boarding School has involved students and society to participate in the plantation sector in Islamic Boarding School Abdussalam, the students not only manage the sector, but the result of its management is also used for the development of facilities and infrastructure of Islamic Boarding School Abdussalam, the community also exist who manages the Islamic Boarding School land with a profit-sharing system, not only that there are also people who sell their plantation products to Islamic Boarding School.

In general, agriculture and plantation activities in Islamic Boarding School Abdussalam have been empowered because of all the activities already produced and already used by the students, this is in line with the opinion Sudantoko (2011: 33) empowerment can be measured by five criteria of business access, market access, access to Informations Technology, access to human resources and lobbying access. When all the access goes it shows that empowerment is done already powerless. While Isma'il (2001: 28) economic activity can be powerless one if it has the ability to meet basic needs of life and a stable economy and in general agriculture and plantations in Islamic Boarding School Abdussalam has produced even though not so stable.

There are two attempts for economic empowerment to be run first to prepare the private community into entrepreneurship, the second doing saving. Both of these things have been done Islamic Boarding School Abdussalam, students are given the opportunity to share the management of agriculture, plantation especially student devotion. 
Agricultural and plantation empowerment of course still have barriers both in the form of internal and external barriers such as transportation facilities and infrastructure, the availability of skilled human resources, capital limitations and the decline in sales (plantation sector). All these obstacles must be resolved so that the empowerment of the agricultural and plantation sectors in Islamic Boarding School Abdussalam can be more empowered.

The scope of development and development of agriculture, plantation, covering the field of post-harvest production and processing, marketing, human resources, and technology. According to Ismail (2001) Guidance and development that can be done and adjusted by researchers with the condition of Islamic Boarding School Abdussalam:

1. Identify potentials and problems faced by farmers. (identifying issues that occurred at Islamic Boarding School Abdussalam)

2. Preparation of development and development programs according to the potential and problems faced (adapted to the condition of agriculture and plantation of Islamic Boarding School Abdussalam)

3. Implementation of development and development programs (can be implemented individually or in groups)

4. Monitoring and control of the implementation of the development and development program (every result of activities performed monitored results that have been done and evaluated)

Based on the four things above, according to the researchers, there are several stages of completion of development and development of agriculture, plantations in Islamic Boarding School Abdussalam as follows:
1. The limitations of transportation facilities and infrastructure: these limitations can be solved by proposing road construction to the local government, although to this extent the road seems very difficult to be realized due to limited government funds, if road construction cannot be done plantation sector in Islamic Boarding School can buy vessels in cooperation with the agricultural sector so that the presence of ships is expected to reduce transportation costs. As for the limitations of internal infrastructure, the agricultural and plantation sectors can cooperate with BMT Barokah Abdussalam through a waqf scheme.

2. Limitations of skilled human resources: these limitations can be solved through cooperation with universities and other institutions both government and private sector, the form of cooperation can be done in the form of in-house training and field practice guidance, product marketing management awareness and comparative study on other Islamic Boarding School which has agricultural and plantation sectors.

3. Capital limitations due to lower sales revenue: these limitations can be solved by utilizing BMT presence in Islamic Boarding School Abdussalam through financing products such as murabaha, musharakah, musharakah mutanaqqishah, ijarah and another financing, this discussion will be specifically explained in detail at material design product empowerment.

4. Decrease in sales results: declining sales of plantation products, Islamic Boarding School needs to cooperate with agents directly, or optimize other crops such as sugarcane and chilli, or plants that have higher selling value and have planting period which is relatively short, so that the 
dependence of the plantation sector on rubber and coriander products is not too impactful, because if the market price of rubber and coriander relative prices continue to decline.

Based on the above discussion, the two sectors have been empowered with and have had a real impact, especially in supporting the independence of Islamic Boarding School Abdussalam although there are still many weaknesses, especially the weaknesses in governance, human resources, infrastructure, and capital. In the previous discussion the researcher has explained how the strategy that can be done by Islamic Boarding School Abdussalam to minimize the whole problem, one of them with more modern management, and establish cooperation that directly focus on solving existing problems in each sector, the cooperation can be done with various government institutions, as well as nongovernmental organizations that have direct links with agriculture and plantation in Islamic Boarding School Abdussalam.

\section{CONCLUSION AND IMPLICATIONS}

\section{Conclusion}

1. The condition of agriculture and plantation in Islamic Boarding School Abdussalam has been empowered and has given economic independence to Islamic Boarding School even though only managed with traditional system, the result of agriculture used by the manager of Islamic Boarding School as a subsidy of student consumption so that the cost of student consumption can be cheaper and affordable, while for the other plantation products used for student consumption, some of the proceeds are used for the development of Islamic Boarding School Abdussalam, although the yield of the plantation is much smaller than that of agriculture because in 2016 and 2017 the price of rubber and decreased, and the two commodities is the largest commodity in the plantation sector in Islamic Boarding School Abdussalam.

2. The proposed agriculture and plantation management design resulting from this research is modern management based on solving major problems faced by both sectors, such as weakness of governance system, lack of professional human resources, limited infrastructure and capital, this matter can be done in cooperation with several related institutions such as government, universities, and companies that are related to the agricultural and plantation sectors in Islamic Boarding School Abdussalam.

\section{Implications}

The implications of this research are expected to be a description of the economic condition, especially agriculture and plantation sector in rural West Kalimantan such as Islamic Boarding School Abdussalam, the management system that has been done in Islamic Boarding School can also be applied by other Islamic Boarding School of course by adjusting with the existing conditions in Islamic Boarding School is still paying attention to any weaknesses in Islamic Boarding School Abdussalam, so it can determine the strategy in accordance with any weaknesses that exist in Islamic Boarding School.

\section{REFERENCE}

Abdurrachim, R. F. (2015). Building Harmony and Peace through Religious : Social Prejudice and Rebeliance Behavior of Students In Modern Islamic Boarding School Gontor Darussalam, East Java. ArRaniry: Internationall Journal of Islamic Studies Vol. 2, No.2., 220.

Adikrishna, N. G. (2011). The Common Room Design of Islamic Boarding 
School: A Preliminary Research in Yogyakarta Islamic Boarding School. International Journal of Engineering \& Technology IJET-IJENS Vol: 11 No: 04, Pp, 127.

Adi, I. R. (2008). Pemberdayaan, Pengembangan Masyarakat

Jakarta: Fakultas Ekonomi Universitas Indonesia.

Alhifni, Huda. (2016). Kinerja LKMS dalam Mendukung Kegiatan Ekonomi Rakyat Berbasis Pesantren. Jurnal Aplikasi Manajemen Vol 1, No 1.Pp 1

Ambar, T,S (2004). Kemitraan dan ModelModel Pemberdayaan. Yogyakarta : Graha Ilmu

Anam, S. (2016). Kurikulum Pesantren Mukimoin Mandiri Waru Sidoarjo Dalam Pengembangan Dunia Usaha. Maraji' : Jurnal Studi Keislaman, No.1 Vol. 3, Pp 306.

Arwiya, E. F. (2015). Building Entrepreneurial Spirit of Islamic boarding school students in Mojokerto Indonesia. Journal of Learning \& Development. Vol. 6, No. 1. Pp, 76.

Ashrohah, H. (2011). The Dynamics Of Pesantren Responses toward Modernity and Mechanism in Organizing Transformation. Journal of Indonesian Islam; ISSN1978-6301, Volume 05, Number 01., 67.

Astuti, M. (2012). Pemberdayaan Perempuan Miskin Berbasis Pemanfaatan Sumber Daya Lokal Melalui Pendekatan Sosial Enterpreneurship. Jurnal Sosio Konsepsia Vol. 17, Vo. 2. Pp, 241245.

Basri, H. T. (2014). Management and Financial Transparency of Islamic Religious Organizations The Case Study of Modern Islamic Boarding School in Contemporary Indonesia. Academic World Education \& Research Center. 02, pp 41-49, Pp, 41-49
Bakhri, S. M. (2011). Sukses Ekonomi Syariah di Pesantren. Pasuruan: Sidogiri Cipta Pasuruan.

Fauzan, A. (2006). Islamic Boarding School dan Pemberdayaan Ekonomi. Jurnal IbdaVo.l. 4.,Pp, $5,7,8$.

Ife, J. d. (2008). Alternatif Pengembangan Masyarakat di Era Globalisasi: Community Development. Yogyakarta: Pustaka Pelajar.

Ismail. (2001). Efektifitas Program IDT dalam Pemberdayaan Masyarakat Miskin di NTT. Yogyakarta: Program Pasca Sarjana Universitas Negeri Yogyakarta.

Indrawati, N. K. (2013). Management by Inspiration: Implementation of Transformational Leadership on Business at Islamic Boarding School Sunan Drajat. Elsevier Ltd. 115, Pp 90.

Mulkan, D. S. (2013). The Study Of Mass Media Use By Islamic Boarding School Students In West Java Province. . The Internasional Jounal Of Social Sciences. Vol.18 No., 24.

Muttaqih, Rizal. (2011). Kemandirian dan pemberdayaan ekonomi Berbasis pesantren (Studi atas Peran Islamic Boarding School Al-Ittifaq Kecamatan Rancabali Kabupaten Bandung terhadap Kemandirian Eknomi Student dan Pemberdayaan Ekonomi Masyarakat Sekitarnya) Jurnal Ekonomi Syariah Indonesia, Volume I, No. 2 PP. 64-94

Rudi, et al (2014). Modal Sosial Pendidikan Islamic Boarding School . Jurnal Harmoni Sosial Vol 1, No.1 $\mathrm{Pp}, 27$

Sari, E. (2016). The Role of Environmental Management Education In Islamic Boarding Schools (Pesantren) In Preventing The Radicalism of Students In Indonesia. . International Journal of Education and Research Vol. 4 No. 7., 402. 
Sulaiman, et al. (2016). Pemberdayaan Koperasi Islamic Boarding School Sebagai Pendidikan Sosial dan Ekonomi Student . Jurnal Pendidikan dan Pemberdayaan Masyarakat. Vol 3, No 2. Pp 109

Sudantoko, D. (2011). Strategi Pemberdayaan Usaha Skala Kecil Batik Dipekalongn. Jurnal Eksplanasi Vol.6 No.129. Pp, $45,33$.

Suharto, E. (2016). Membangun Masyarakat Memberdayakan Rakyat: Kajian Strategis Pembangunan Kesejahteraan Sosial dan Pekerjaan Sosial Kajian Strategis Pembangunan Kesejahteraan Sosial dan Pekerjaan Sosial. Bandung. Bandung: Refika Aditama.
Sukirno, S. (2003). Makro Ekonomi Teoridan Pengantar. Jakarta: Raja Grafindo.

Thahir, M. (2014). The Role and Function of Islamic Boarding An Indonesian Context. Tawarikh:International Journal for Historical Studies, 5(2)., $198 \& 210$.

Putra, A. (2012). Perencanaan Pendidikan di Sekolah Madrasah, dan Islamic Boarding School . Jurnal Idaroh Vol 1, No 1, 78.

Wekke, I. S. (2013). Religious Education And Empowerment, Study on Pesantren in Muslim Minority West Papua. MIQOT Vol. XXXVII No. 2, Pp,386. 